\section{Quantitative Dot- Immunoblot Assay to Measure Protein in Multiple Brain Samples}

BioTechniques 20:809-811 (May 1996)

Western blotting (1) is frequently used to detect changes in the amount of protein in tissue after injury or with disease, particularly if the concentration of the protein is low. However, this technique has several limitations. The procedure is time-consuming and only a few samples can be assayed at any given time. Furthermore, Western blotting is subject to variations in protein loading and requires electrophoretic transfer, factors which limit the ability to make quantitative estimates of the amount of protein in the sample. In dotimmunoblotting, many samples can be assayed simultaneously, and protein transfer is not necessary, since the sample is directly applied to the nitrocellulose membrane (2). We modified the quantitative dot-immunoblot technique described by Jahn et al. (3), improving the reproducibility and reliability by which measurement of the amount of protein in tissue samples can be made. In this assay, purified protein is used to generate a standard curve and this curve is used to determine the absolute amount of protein present in the tissue homogenates. Detection is by direct counting of radioactivity rather than by densitometric analysis. By minimizing adsorption of protein to plastic, by improving the application of the sample to nitrocellulose, by correcting for nonspecific binding in crude homogenates and by directly counting radioactivity, nanogram quantities of protein can be reliably detected in tissue samples. We describe the use of this assay to measure the amount of neurofilament (NF) $200-\mathrm{kDa}$ protein in different regions of the brain in rabbits subjected to cerebral hypoxia-ischemia and reperfusion.

To inflict brain injury, anesthetized, immature male rabbits were subjected to cerebral hypoxia-ischemia and reperfusion by using a recently developed model (4). Rabbits first breathed $2.5 \%$ oxygen for $8 \mathrm{~min}$ and then $8 \mathrm{~min}$ of cerebral ischemia was induced by rais-
Table 1. Regional Brain Neurofilament 200-kDa Protein ${ }^{\mathrm{a}}$ in Hypoxic-Ischemic and Control Rabbits

\begin{tabular}{|lccccc|}
\hline & \multicolumn{5}{c|}{ Brain Region } \\
\cline { 2 - 6 } Animalb & Hippocampus & Caudate & Thalamus & Cortex & Cerebellum \\
\hline HI\#1 & 92.2 & 17.2 & 67.3 & 46.2 & 63.9 \\
HI\#2 & 53.5 & 25.8 & 67.5 & 53.3 & 70.7 \\
CTL & 58.2 & 14.6 & 33.6 & 27.3 & 40.4 \\
aNanograms neurofilament 200-kDa protein/ $\mu$ total protein \\
bHI = Hypoxic-ischemic rabbit; CTL = sham-operated control rabbit \\
The values were calculated using the regression equation in Figure 2. \\
\hline
\end{tabular}


ing intracranial pressure equal to mean arterial pressure by infusing an artificial cerebrospinal fluid into the subarachnoid space. To initiate reperfusion, cerebrospinal fluid was drained until intracranial pressure was $\leq 20$ $\mathrm{mmHg}$. Control animals were subjected to the same operative procedure without hypoxia-ischemia. After $4 \mathrm{~h}$ of reperfusion, the rabbit was sacrificed with intravenous potassium chloride, and the brain was rapidly removed and chilled in liquid nitrogen. Specific brain regions were dissected on a glass plate over ice and homogenized at 1:4 (wt/vol) in ice-cold $63 \mathrm{mM}$ Tris- $\mathrm{HCl}$ with $10 \%$ glycerol, $2 \%$ sodium dodecyl sulfate (SDS), $1 \mathrm{mM}$ dithiothreitol (DTT), $1 \mathrm{mM}$ EDTA and $0.5 \mathrm{mM}$ phenylmethylsulfonyl fluoride (PMSF), $\mathrm{pH}$ 6.8, using a Tissue Tearor (Bio Spec Products, Racine, WI, USA) at speed 2.5. Samples were centrifuged at $18000 \times g$ at $4^{\circ} \mathrm{C}$ to remove particulate matter and stored at $-70^{\circ} \mathrm{C}$ until assayed. Protein concentration was determined by using the Pierce BCA assay (5).

Prior to the dot-immunoassay, all test tubes were soaked in $1 \%$ non-fat dry milk overnight at $4^{\circ} \mathrm{C}$ to minimize adsorption of protein to the plastic. To generate the standard curve, various dilutions of NF $200-\mathrm{kDa}$ protein were prepared from a stock solution made from purified NF $200-\mathrm{kDa}$ protein (American Research Products, Bel-

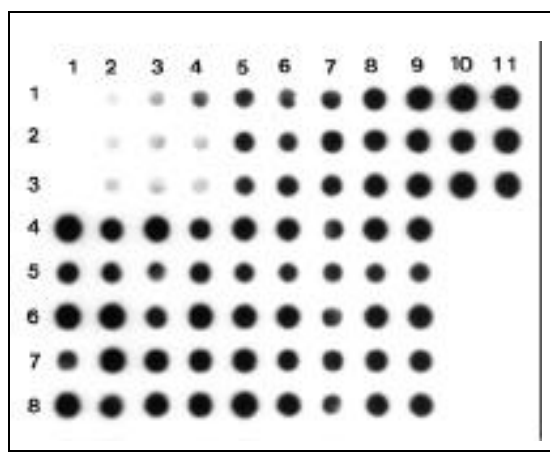

Figure 1. Neurofilament 200-kDa dot-immunoblot: standard/sample section. Rows 1-3: Standard curve. Column 1, buffer; Columns $2-11$, purified neurofilament $200-\mathrm{kDa}$ protein (4, $8,16,32,64,128,192,256,384,512$ ng). Rows 4-8: Rabbit brain. Hippocampus (row 4), caudate (row 5), thalamus (row 6), cortex (row 7), cerebellum (row 8). Columns 1-3, Hypoxic-ischemic rabbit \#1; Columns 4-6, Hypoxic-ischemic rabbit \#2; Columns 7-9, Sham-operated control rabbit. mont, MA, USA) diluted in $10 \mathrm{mM}$ sodium phosphate, $6 \mathrm{M}$ urea, $2 \mathrm{mM}$ DTT, 1 mM EDTA and $0.02 \%$ SDS, pH 7.4. The solutions were prepared such that the final amounts of NF protein applied to the blot were $4,8,16,32,64$, $128,192,256,384$ and $512 \mathrm{ng}$. Prior to the assay, the purity of the protein was confirmed by Western blotting (1). Brain samples were prepared in a similar fashion with the same buffer such that the final amount of total protein applied was $4 \mu \mathrm{g}$. Three hundred microliters of standard or sample were applied in triplicate under low vacuum to a prewetted $0.45-\mu \mathrm{m}$ nitrocellulose membrane (Micron Separations, Westborough, MA, USA) using a dot-blot apparatus (HYBRI-DOT ${ }^{\circledR}$ Manifold; Life Technologies, Gaithersburg, MD, USA). Chromatography filter paper (3MM; Whatman, Clifton, NJ, USA) was placed under the nitrocellulose to improve vacuum distribution, substantially increasing sample reproducibility. In one section of the blot ("ascites" section), additional amounts of standard and sample were applied. This section was used to correct for nonspecific binding in the crude homogenates.

The entire blot was blocked in 200 $\mathrm{mL}$ of $5 \%$ non-fat dry milk and $0.1 \%$ Tween ${ }^{\circledR} \quad 20$ in phosphate-buffered saline (PBS) for one hour at room temperature. Subsequently, the filter was divided into 2 parts. The standard/sample section was incubated with a mouse monoclonal antibody specific for NF 200 kDa (clone N52; Sigma Chemical, St. Louis, MO, USA) at 1:10000 (specificity of the antibody was previously verified with Western blotting),

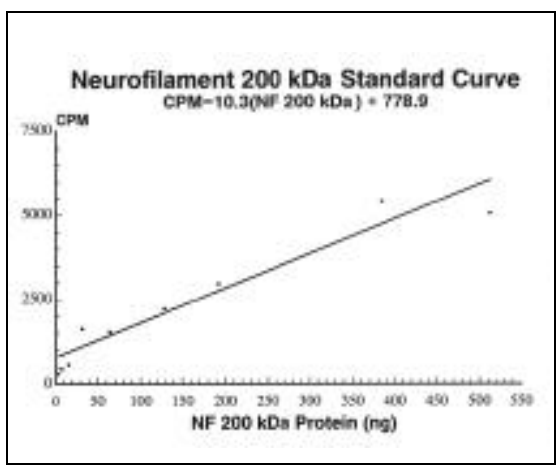

Figure 2. Regression curve and equation derived from the neurofilament $200-\mathrm{kDa}$ standards. $r^{2}=0.95(P<0.001)$. while the "ascites section" was exposed to mouse $\operatorname{IgG}_{1}$ in ascites fluid (Sigma Chemical). Each blot was exposed to the same amount of total protein mixed in $1 \%$ non-fat dry milk and $0.05 \%$ Tween-20 in PBS. Both sections were incubated overnight at $4^{\circ} \mathrm{C}$. The blots were washed three times in $0.1 \%$ Triton ${ }^{\circledR}$ X-100 in PBS, once in PBS and then exposed to ${ }^{125}$ I-labeled goat-[antimouse] IgG antibody (ICN Pharmaceuticals, Costa Mesa, CA, USA) at $200000 \mathrm{cpm} / \mathrm{mL}$ for $90 \mathrm{~min}$. After washing three times in $0.1 \%$ Triton X100 in PBS, the blots were subjected to autoradiography (FUJI RX; Fuji Film, Tokyo, Japan) for $24 \mathrm{~h}$.

Using the autoradiogram as a guide, the dots were cut out using a hole puncher and the radioactivity was determined in a gamma counter (Cobra Auto-Gamma; Packard, Meriden, CT, USA). Samples were blank corrected by subtracting the counts from the corresponding region of the "ascites" section. A regression equation was generated from the standards using statistical software (GB-Stat, Version 3.0; Dynamic Microsystems, Silver Spring, MD, USA). Analysis revealed that linear regression was the best fit. The amount of NF 200-kDa protein in each sample was calculated using the standard curve.

Shown in Figure 1 is an autoradiogram from a representative dot-immunoblot. In this blot, NF $200-\mathrm{kDa}$ protein was measured in five brain regions in 3 rabbits. Two animals were subjected to cerebral hypoxia-ischemia, and one was a sham-operated control. The regression equation generated from the standards is shown in Figure 2 . There was an excellent linear correlation between counts per minute and NF 200-kDa protein with a correlation coefficient of 0.95 ( $P<0.001)$. The average coefficient of variation of the triplicates was $18 \%$. The amount of NF 200-kDa protein in the brain samples was calculated from the standard curve and is displayed in Table 1. Values ranged from a high of $92.2 \mathrm{ng}$ NF 200 $\mathrm{kDa} / \mu \mathrm{g}$ total protein in the hippocampus to a low of 14.6 in the caudate.

This assay has exhibited excellent reproducibility. It is easy to perform, allows many samples to be analyzed at the same time and gives a quantitative 
result. It can easily be adapted to measure other brain proteins. We have also used it to measure the amount of neurofilament of $68 \mathrm{kDa}$ and class III $\beta$-tubulin in the brain. This assay will aid in measuring small changes in protein concentration after tissue injury or disease, especially when a large number of samples need to be evaluated.

\section{REFERENCES}

1.Burnette, W.N. 1981. "Western blotting": electrophoretic transfer of proteins from sodium dodecyl sulfate-polyacrylamide gels to unmodified nitrocellulose and radiographic detection with antibody and radioiodinated protein A. Anal. Biochem. 112:195-203.

2.Hawkes, R., E. Niday and J. Gordon. 1982. A dot-immunobinding assay for monoclonal and other antibodies. Anal. Biochem. 119:142-147.

3.Jahn, R., W. Schiebler and P. Greengard. 1984. A quantitative dot-immunobinding assay for proteins using nitrocellulose membrane filters. Proc. Natl. Acad. Sci. USA 81:1684-1687.

4.Mink, R.B. and A.N. Manepalli. 1995. Regional cerebral blood flow during and after hypoxia-ischemia in rabbits. Crit. Care Med. 23:A208.

5.Smith, P.K., R.I. Krohn, G.T. Hermanson, A.K. Mallia, F.H. Gartner, M.D. Provenzano, E.K. Fujimoto, N.M. Goeke, B.J. Olson and D.C. Klenk. 1985. Measurement of protein using bicinchoninic acid. Anal. Biochem. 150:76-85.

This work was supported by a grant from the Fleur-de-Lis Foundation. Address correspondence to Richard B. Mink, Department of Pediatrics Cardinal Glennon Children's Hospital, 1465 South Grand Blvd., St. Louis, MO 63104, USA. Internet: richard-m@wpogate.slu.edu

Received 2 October 1995; accepted 19 December 1995.

Richard B. Mink and Jill A. Johnston

St. Louis University

Cardinal Glennon Children's Hospital

St. Louis, MO, USA 